\title{
PROTHONOTARY WARBLER IN WINNIPEG, MANITOBA
}

ROBYN M. UNDERWOOD, Department of Entomology, University of Manitoba, Winnipeg, MB R3T 2N2, Email: umunder0@cc.umanitoba.ca, and TODD J. UNDERWOOD, Department of Zoology, University of Manitoba, Winnipeg, MB R3T 2N2

On 12 May 2001 at 9:40 AM, RMU spotted an unusual warbler about $5 \mathrm{~m}$ away in the cattails at the edge of the pond at King's Park in Winnipeg, Manitoba. The warbler then flew across the water about $40 \mathrm{~m}$ to another cattail patch. We moved around the shore to get a better look from approximately 20 $\mathrm{m}$. It was a warm, sunny day that provided excellent conditions for viewing.

The warbler was yellow from head to breast and had grayish wings without wing-bars. Its undertail coverts and belly were white. The yellowish colour of the back of its head became slightly olive toward and on the back. The bill was blackish and the eye was dark with no eyeline. The bird was a Prothonotary Warbler (Figure 1). The warbler foraged low in the dead cattails, occasionally flying and perching at the top of the cattails before dropping back down. At 10:15 AM, it flew to a small tree on the bank of the pond and perched $4 \mathrm{~m}$ high for 2 minutes, after which it flew back into the cattails. We watched and videotaped the bird foraging until 10:50 AM when we left the park.

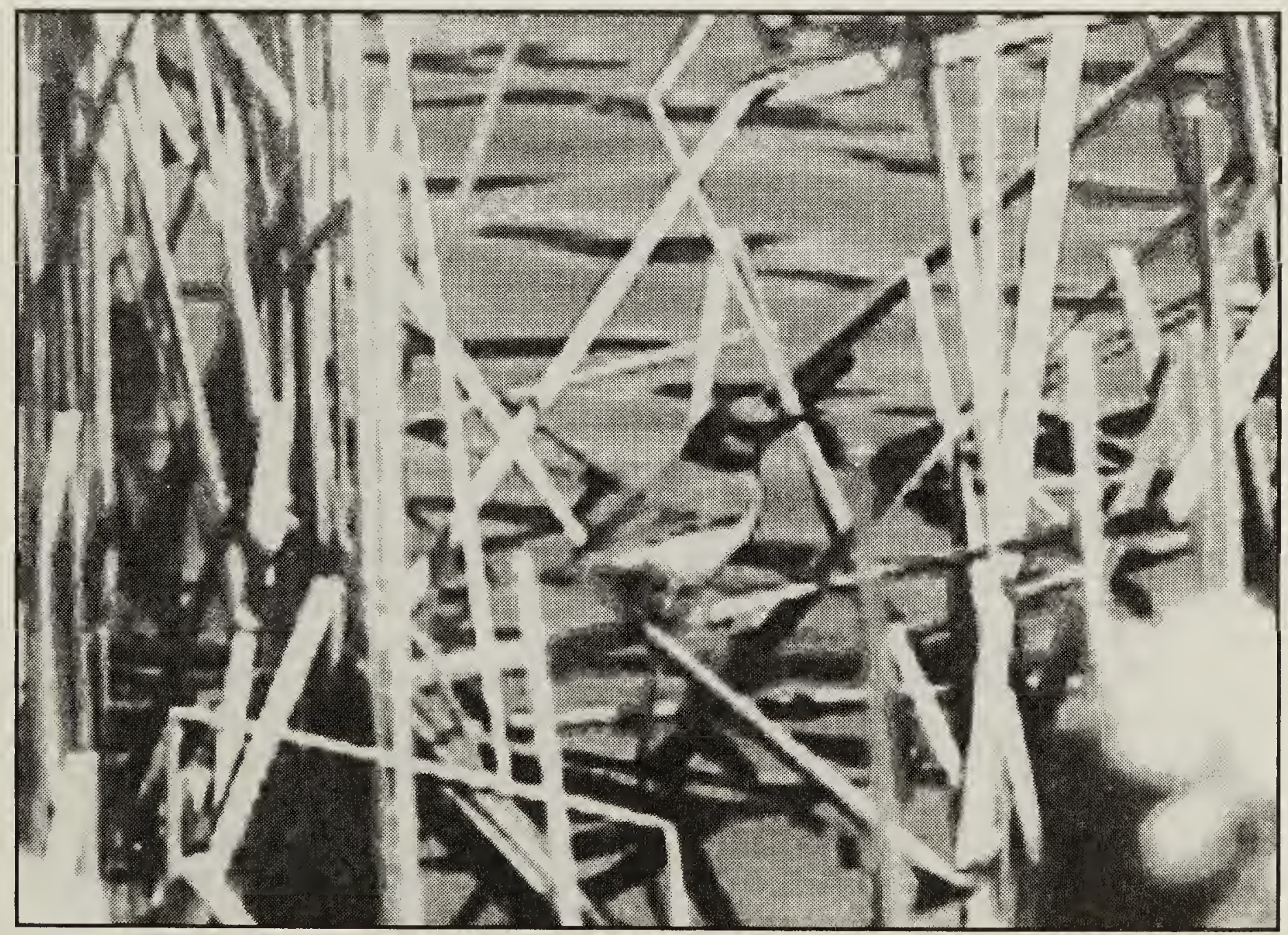

Figure 1. Prothonotary Warbler in King's Park, Winnipeg on 12 May 2001. Photograph from video by T. J. Underwood. 
We returned to the park with Spencer Sealy at 12:30 AM and quickly relocated the warbler in the cattails on the west side of the pond. We watched and videotaped the warbler for about 3 minutes from a distance of about $5 \mathrm{~m}$. The Prothonotary Warbler was re-located at 6:45 PM along the bank of the Red River just west of the pond by Ron Austin, Gordon and Jaye Grieef, George Holland, Carolyn Curtis and Red Clarke. The bird was not reported again.

We did not hear the bird vocalize, nor did others who saw it. Initially, we believed the warbler was a female because of its relatively dull appearance. However, the warbler appeared brighter on the videotape and other birders suggested it may have been a first-year male or a female.

There are three previous reports of Prothonotary Warblers in Manitoba. The first bird, believed to be a male, was discovered by Spencer Sealy at Delta Marsh on 17 May $1989^{5}$ and also was seen by Ronald Bazin and Diane Neudorf (Spencer Sealy, pers. comm.). The second Prothonotary Warbler, a male, was reported by Martin Siepman on 31 July 1990 at Birch Point on Buffalo Bay, Lake of the Woods. ${ }^{5}$ Andy Courcelles discovered the third bird, a female or immature male (R.F. Koes, pers. comm.), on 3 October 1997 in St. Adolphe. ${ }^{6}$ Only the third sighting was confirmed because the previous two records lacked documentation. Appropriate documentation for a sight record includes any one of the following: a photograph, a videotape, a voice recording, or independently written reports by at least two competent observers. ${ }^{7}$ Colour photographs from our videotape will be retained on file with the Manitoba Ornithological Records Committee. This sighting of the Prothonotary Warbler in Winnipeg has been accepted by the committee and is the second confirmed sighting in Manitoba.

Prothonotary Warblers nest in wet lowland forests in the southeastern and central United States and a few areas in southern Ontario. ${ }^{8}$ However, the breeding area closest to Manitoba is in the Mississippi River and Minnesota River valleys of southern Minnesota..$^{3,2}$ Prothonotary Warblers are well known as vagrants in much of North America. There are records for several eastern Canadian provinces and numerous records throughout the western United States (over 150 records for California alone!). ${ }^{1}$ There are a few sight records from northern Minnesota, ${ }^{3,4}$ at least 1 from northwestern Ontario, ${ }^{10}$ and 7 records from Saskatchewan (4 in spring and 3 in fall). ${ }^{9}$

\section{Acknowledgements}

We thank J. F. Hare for assistance with the photograph, R. F. Koes and S. G. Sealy for providing information and commenting on this paper, and the others who saw the bird and shared with us their observations.

\section{Dunn, J. L. and K. L. Garrett. 1997. A} Field Guide to Warblers of North America. Houghton Mifflin Company, Boston, MA.

2. Hertzel, A. X. and R. B. Janssen. 1998. County nesting records of Minnesota birds. Minnesota Ornithologists' Union Occasional Papers No. 2, Minneapolis, MN.

3. Janssen, R. B. 1987. Birds in Minnesota. University of Minnesota Press, Minneapolis, MN.

4. Janssen, R. B. and A. X. Hertzel. 1996. County occurrences of Minnesota birds. Minnesota Ornithologists' Union Occasional Papers No. 1, Minneapolis, MN. 
5. Koes, R. F. 1991. Additions to the Manitoba bird list (1985-1990). Blue Jay 49:202-207.

6. Koes, R. F. and P. Taylor. 1998. Prairie provinces region. Field Notes 52:76-79.

7. Manitoba Avian Research Committee. 2000. Manitoba bird checklist, revised. Manitoba Naturalists Society, Winnipeg, MB.

8. Petit, L. J. 1999. Prothonotary Warbler (Protonaria citrea). In: Poole,
A. and F. Gill (eds.). The Birds of North America, No. 408. The Birds of North America, Inc., Philadelphia, PA.

9. Smith, A. R. 1996. Atlas of Saskatchewan Birds. Special Publication No. 22, Saskatchewan Natural History Society, No. 4 Manley Callin Series, Regina, SK.

10. Speirs, J. M. 1985. Birds of Ontario. Natural Heritage/Natural History Inc., Toronto, ON.

\title{
PURPLE MARTINS ATTRACTED TO GRASSWOOD
}

\author{
GERALD J. PARENT, RR\#5, Station Main, Saskatoon SK S7K 3J8
}

In 1987, my wife and I moved to an acreage located four miles south of Saskatoon. This location, the old Grasswood Saskatchewan Wheat Pool grounds, is well treed as a result of plantings years ago by my in-laws, Jack and Lillian Briggs.

After retirement in 1995 , I put a birdbath in the garden and my wife bought me some bird feeders. In 1998 , I put out a metal Purple Martin house with 12 cavities which was given to me by a friend, and four single-cavity super gourds from the Purple Martin Conservation Association (PMCA). That year nothing came.

In 1999 a few pairs of martins visited but none stayed. I read an article about the social attraction method developed by Steven Kress, a Cornell University biologist trying to reestablished Atlantic Puffin colonies. Colonial birds have a strong preference to nest in close proximity to each other and Kress reasoned that if he could trick migrating puffins into believing that former colony sites were active, they would stay and attempt to breed. His technique involved the use of decoys, vocalizations, fake nests and mirrors. The social attraction method is ultimately the art of deception, trickery and manipulation to establish a breeding colony.

I started trying to attract Purple Martins by putting up some wooden Purple Martin decoys. I got decoy plans from the Purple Martin Forum on the 